\title{
Effect of Profitability Ratio, Solvency, Market Ratio, Andrisk Ratio on Stock Return
}

\author{
Januar Afrino ${ }^{1}$, Erni Masdupi ${ }^{2}$ \\ ${ }^{1}$ Universitas Negeri Padang, Padang, Indonesia, $\square$ januarafrino.95@gmail.com \\ ${ }^{2}$ Universitas Negeri Padang, Padang, Indonesia, $\square$ emasdupi@yahoo.com
}

\begin{abstract}
Bank is a financial institution that very play an important role in to improve economic conditions in indonesia that bank being one investors to investment. The research aim to understand the influence of ROA, CAR, DER, PER and Beta to return of the shares of bank listed on the indonesian stock in the period 2013-2017. Independent Variable used inside this research is ROA, CAR, DER, PER and Beta while for dependent variables is return stock .Sample used inside this research thirty-one bank, using the technique the sample is purposive sampling. Analysis of data using multiple linear regression. The results of the study is ROA will not affect return the bank stocks, CAR will not affect return the bank stocks, DER will not affect return the bank stocks , PER influential positive and significantly to return the bank stocks and Beta influential positive and significantly to return the bank stocks
\end{abstract}

Keywords: ROA, CAR, DER, PER, Beta and Return Stock

\section{Introduction}

The capital market is one of the economic instruments developed today which is very rapidly developed in the capital market that is made an indicator of the progress of the country that can support the country's economy as needed. One form of investment that began to attract interest as investors was stock investment through the stock exchange. Every investor prefers to buy shares of companies that go public, because the company's shares go public as an investment commodity classified as promising high returns but also have a high risk due to the nature of the commodity which is very sensitive to changes in politics, economy, monetary, government policies, both changes abroad or domestically.

One of the subsectors that investors are interested in investing in is the bank subsector because banks are financial institutions that are very important in improving the Indonesian economy so that this is considered by investors as a good signal in investing. Based on data obtained in the financial sector, it is the bank sub-sector that has the highest average share price compared to other sub-sectors, but this bank has the highest number of companies that experience a decline in stock returns. This is inversely proportional to the existing theory, where according to the theory if the stock price is high then the rate of return (return) will also be high.

To conduct an analysis of stock returns, there is a need for fundamental and technical information (Halim, 2005). Fundamental analysis is based on information published by issuers and stock exchange administrators. While technical analysis is based on stock price data in the past as an attempt to estimate stock prices in the future (Halim, 2005). Fundamental analysis is influenced by financial ratios which is one indicator of the company's financial performance. The measurement of conventional financial performance that is important and usually the center of attention of investors and financial analysts includes analysis of the position of the company's competitive advantage, the liquidity of the company's assets, especially those related to the company's financial ability to fulfill its short-term obligations.

In this study the financial ratios used are ROA, CAR, PER, and DER this is because the mapping of previous research obtained the phenomenon of gaps from the results of research and also the three ratios based on theory is the closest ratio that can affect stock returns. 
According to Jogiyanto (2010) the capital market is a place to meet between sellers and buyers with a risk of profit or loss. Whereas according to Sunariayah (2006), the capital market is an organized financial system, including commercial banks and all intermediary institutions in the financial sector, as well as all outstanding securities. Capital markets have two functions, namely economic functions and financial functions.

According to Law No.10 of 1998, a bank is a business entity that collects funds from the public in the form of deposits and redistributes to the community in the form of loans that are useful to improve the lives of many people. bank functions according to Siamat (2005), namely:

1. Providing mechanisms and means of payment that are more efficient in economic activities.

2. Creating money.

3. Collect and channel funds to the community.

4. Offering other financial services.

Investment is a delay in current consumption for use in efficient production over a period of time (Jogiyanto, 2010). Meanwhile, according to Halim (2005), investment is the placement of a number of funds at this time in the hope of gaining profits in the future. So based on some understanding of investment above, it can be concluded that investment is an activity in the financial or financial field that aims to obtain or obtain a maximum yield of wealth or assets planted. According to Tandelilin (2010), investor attitudes in dealing with risks can be classified into three groups, namely:

1. Risk Seeker Namely the investors who, when faced with two alternative choices with the same return, then he would prefer investments that tend to be at risk.

2. Risk Avoidance (Risk Averter) Namely, investors who, when faced with two investment alternatives whose returns are the same, will prefer investment with a smaller risk.

3. Risk Indifference Namely investors who do not care about the risks they receive from the type of investment they will take.

\section{Return and Risk \\ Return}

According to Tandelilin (2010), return is the level of profits received by investors from a number of funds that have been issued. In general, the higher the risk of investment, the higher the expected return. The return expected by each investor from the investment made is compensation for the opportunity cost and the return that is realized.

\section{Risk}

In general, the goal of every investor to invest funds is to get profits from the investment he does. Investors do not know for sure the results they will get. Therefore, it can be said that investors face risks to the investments they make.

According to Halim (2005), risk is the amount of deviation between the level of expected return and the actual return. The greater the level of difference means the greater the level of risk. According to Tandelilin (2010), risks can be divided into two types, namely:

1. Systematic Risk

2. Unsystematic Risk

\section{Methods}

This study is a research to see the impact of services quality, location and word of mouth to repurchcasing intention through brand image at Muslim salon beauty care Padang. Population in this study is all consumers who visit Muslim salon beauty care Padang with sample size of 150 respondents, selected based on purposive sampling. Criteria for selecting sample in this study is for consumers who have already came more thanonce, over 17 years old and live in Padang. Data analysis technique used is path analysis using PLS.

The population used in this study are banks listed on the Indonesia Stock Exchange, which are 41 banks. (Source from www.idx.co.id and www.icmd.co.id).According to Sugiyono (2010), the sample 
is part of the number and characteristics possessed by the population. The sampling technique used in this study uses purposive sampling, which is a sampling technique based on consideration of certain criteria (Sugiyono, 2010). Where the criteria of the banks sampled in this study are:

1. Banks listed on the IDX during the 2013-2017 observation period.

2. Companies that regularly publish financial statements from $2013-2017$.

Based on the above criteria, the samples used in this study were 31 banks listed on the Stock Exchange in 2013 until 2017. While the data used in this study is panel data, where the panel data is a combination of time series data and data cross section. The method of data collection in this study was carried out by means of documentation from http://www.icmd.co.id and www.idx.co.id.

\section{Dependent variable ( $Y)$}

The dependent variable used in this study is stock returns. Stock return is the level of profits received by investors from a number of funds that have been issued (Tandelilin, 2010).

Stock Return $=$

$$
\frac{P t-(P t-1)}{(P t-1)}
$$

\section{Independent variable $(X)$}

Return on Asset (ROA) is a ratio that is used to measure a bank's ability to earn profits over a period of time (Munawir, 2010). Systematically ROA can be formulated as follows (Hanafi and Halim, 2003)

ROA $=\frac{\text { Net Profit }}{\text { Total Asset }}$

Capital Adequacy Ratio (CAR)

Adequac Capital is a ratio used to see how much capital a company has. Systematically CAR can be formulated as follows (Kasmir, 2010):

\section{CAR $=\frac{\text { Tier } 1 \text { Capital }+ \text { Tier } 2 \text { Capital }}{\text { Risk Weighted Assets }}$}

Debt to Equity Ratio (DER)

Debt to equity ratio is the ratio used to see how much total debt a company has. Systematically DER can be formulated as follows (Kasmir, 2010):

$\mathrm{DER}=\frac{\text { Total liability }}{\text { Owner sequity }}$

Price Earning Ratio (PER)

Price Earning Ratio (PER) is a ratio between the price of a share and the income of each share. Systematically PER can be formulated as follows (Tandelilin, 2010):

$$
\mathrm{PER}=\frac{\text { Stock price }}{\text { stock sheet profit }}
$$

Beta

The relative size of systematic risk is known as the $\beta$ coefficient (beta) which shows the size of the relative risk of a stock systematically PER can be formulated as follows (Jogiyanto, 2010)

$\beta i=\frac{\operatorname{Cov}(\mathrm{Ri}, \mathrm{Rm})}{\operatorname{Var}(\mathrm{Rm})}$ 


\section{Results And Discussion}

\section{Effect of Return of Assets (ROA) on Bank Stock Returns}

Based on the multiple linear regeresi testing that has been done the results obtained indicate that the probability value is $0.53>$ alpha 0.05 , then the decision is that Ho is accepted so Ha is rejected. This means that Return on Asset does not affect stock returns. The results obtained from this test are inconsistent with the description of the theory and hypothesis proposed. This deviation occurs because investors no longer use ROA as a tool to see the level of profit, but investors take into account other profitability ratios such as ROE. This is because ROA is a ratio used to see how much the overall profit level of the company. Whereas ROE is the ratio used to see how much net profit they will receive later so that this makes investors more take into account ROE than ROA.

\section{Effect of Capital Adequacy Ratio (CAR) on Bank Stock Returns}

Based on the hypothesis testing that has been done obtained a regression coefficient value for the variable capital adequacy ratio of -0.004 with a probability value of 0.77 . The results obtained indicate that the probability value is $0.77>$ alpha 0.05 , then the decision is that Ho is accepted and $\mathrm{Ha}$ is rejected, which means that the capital adequacy ratio does not affect stock returns. The results obtained from this study contradict (inconsistent) with the theory and hypotheses proposed. Based on this study, it can be seen that banks have a high average CAR value of 16.45 which exceeds the minimum CAR value requirement that the bank must have at $8 \%$ so this does not cause investors to worry about investing in the company, by therefore investors are less concerned about CAR.

\section{Effect of Debt to Equity Ratio (DER) on Bank Stock Returns}

Based on the hypothesis testing that has been done, the regression coefficient is obtained for the Debt to Equity Ratio variable of -0.013 with a probability value of 0.45 . The results obtained indicate that the probability value is $0.45>$ alpha 0.05 , then the decision is that Ho is accepted and Ha is rejected, which means partially Debt to Equity Ratio does not affect stock returns. The results obtained in this test contradict or are not consistent with the theory and hypothesis proposed. In this study it can be seen that banking companies have a high DER value, but this company is still able to carry out its operational activities to generate profits and also this company is able to pay its debts because in general the bank's capital comes from debt so this does not reduce investor interest in investing

\section{Effect of Price Earning Ratio (PER) on Bank Stock Returns}

Based on the hypothesis testing that has been done, the regression coefficient value for the variable is 0.018 with a probability value of 0.00 . The results obtained indicate that the probability value is 0.00 $<$ alpha 0.05 , then the decision is Ho is rejected and Ha is accepted which means that Price Earning Ratio has a positive effect on stock returns. The positive direction in question is that if Price Earning Ratio increases, the stock return will also increase. The results obtained in this test are consistent with both theory and hypotheses. This is because the PER shows the prospect of the stock price being valued higher by investors, therefore the higher PER indicates the higher the price of the stock towards its income. By knowing the size of the prospect of stock prices, more and more investors will be interested in investing their funds as a result of which stock prices will rise and have an impact on rising stock returns.

\section{Relationship of Beta $(\beta)$ on Bank Stock Returns}

Based on the hypothesis testing that has been done, the regression coefficient value for the variable is 0.333 with a probability value of 0.01 . The results obtained indicate that the probability value is 0.01 $<$ alpha 0.05 , then the decision is Ho is rejected and Ha is accepted. This means that beta $(\beta)$ is positively related to stock returns. The results obtained in this study are consistent with the theory and hypothesis used because beta is a measure of systematic risk that is closely related to stock 
returns. Closely related here means that stocks that have the potential to have high profits will also have high risk or can be termed high risk high return (Tandelilin, 2010).

\section{Conclusion}

Based on the results of a hypothetical study that has been done, it can be concluded that ROA, CAR, DER has no effect on the return of bank shares listed on the Indonesia Stock Exchange in 20132017 while PER and Beta have a positive and significant effect on the stock return listed in Indonesia Stock Exchange in 2013-2017.

Based on the results of testing and data analysis, the authors propose several suggestions that can provide positive benefits for further researchers, namely:

1. It is recommended for further research to use financial ratios other than ROA, CAR and DER because based on this study it was found that the three ratios did not significantly influence stock returns. This might be because there are other factors that affect the variable ROA, CAR and DER.

2. It is recommended for further research that researchers should extend the observation period so that later the results obtained are more accurate.

3. It is recommended in future studies to add other independent variables that have not been included in this study such as macroeconomic variables, namely: inflation, exchange rate, interest rates and others. This is important to do to get better results.

The implication of this research are :

1. For company managers, can be used as a consideration in looking at the company's financial condition so that later can take the right alternative in increasing the profitability of the company so that it will be interesting to ask investors to invest in the company.

2. For investors and potential investors, it can be used as an alternative consideration before investing in a company so that investors can get a return or profit in accordance with what they expect.

\section{References}

Bank Indonesia. 1998. Tentang Perubahan Undang-undang Republik Indonesia. No. 10 dan 19. Jakarta: Bank Indonesia.

Faisol, Ahmad. 2007. Analisis Kinerja Keuangan Bank Pada PT. Bank Muamalat Indonesia, Tbk. Jurnal Ilmiah Berkala Empat Bulanan. Vol3 No 2.

Halim, Abdul. 2005. Analisis Investasi, Edisi Dua, Jakarta: Salemba Empat.

Hanafi, Mamduh M, dan Abdul Halim. 2003. Analisis Laporan Keuangan. Yogyakarta: UPP AMP YKPN.

Jogiyanto, Hartono. 2010. Teori Portofolio dan Analisis Investasi. Yogyakarta: BPFE.

Kasmir. 2010. Pengantar Manajemen Keuangan. Jakarta: Kencana.

Munawir, S. 2010. Analisa Laporan Keuangan. Edisi Keempat. Yogyakarta: Liberty.

Riyanto, Bambang. 2008. Dasar-dasar Pembelajaran Perusahaan. Edisi Empat. Yogyakarta: BPFE.

Siamat, Dahlan. 2005. Manajemen Lembaga KeuanganKebijakan Moneter dan perbankan. Edisi lima. Jakarta: LPFEUI.

Sugiyono. 2010. Metode Penelitian Bisnis. Bandung: Penerbit Alfabeta.

Sunariyah. 2006. Pengantar Pengetahuan Pasar Modal. Yogyakarta: STIM YKPN.

Tandelilin, Eduardus. 2010. Portofolio dan Investasi Teori dan Aplikasi. Edisi Pertama. Yogyakarta: KANISIUS.

Winarno, Wing wahyu. 2009. AnalisisEkomometrika dan Statistik dengan Eviews. Edisi kedua. Yokyakarta: STIM YKPN.

www.Idx.co.id

$\underline{\text { www.icmd.co.id }}$ 